\title{
Rhodobacter marinus sp. nov.: a new marine hydrogen producing photosynthetic bacterium which is sensitive to oxygen and sulphide
}

\author{
J. Grant Burgess, Ryuji Kawaguchi, Akiyo Yamada \\ and Tadashi Matsunaga
}

Author for correspondence: J. Grant Burgess. Tel: +81423814221 ext. 559. Fax : +81 423857713.

Department of

Biotechnology, Tokyo

University of Agriculture

and Technology, Koganei,

Tokyo 184, Japan

\begin{abstract}
A new non sulphur photosynthetic bacterium, strain NKPB 0021, was isolated from sea water samples and assigned to the genus Rhodobacter on the basis of morphology and presence of vesicular photosynthetic membranes. Cells are motile rods, 0.6-1.2 $\mathrm{\mu m}$ in diameter and multiply by binary fission. This isolate is unusual since it is oxygen sensitive and cannot grow aerobically. Strain NKPB 0021 grows best anaerobically in the light and requires $\mathrm{NaCl}$ for growth (optimum 1.5\%). Cells are capable of assimilatory sulphate reduction, and are sensitive to sulphide, with no growth above $0.7 \mathrm{mM}$ sulphide. The mean DNA base composition is $66.7 \mathrm{~mol} \% \mathrm{G}+\mathrm{C}$. On the basis of this study, we propose strain NKPB 0021 to be the type strain of a new species, Rhodobacter marinus.
\end{abstract}

Keywords: Rhodobacter marinus sp. nov., non sulphur photosynthetic bacteria, marine hydrogen photoproduction, sulphate reduction

\section{INTRODUCTION}

Species of the genus $R$ bodobacter are among the most metabolically versatile of all bacteria, since they can perform a number of different growth modes (Imhoff \& Trüper, 1989). The freshwater species, R. sphaeroides and $R$. capsulatus, have been used extensively as model systems for the study of photosynthesis and nitrogen fixation (Scolnik \& Marrs, 1987; Willison, 1993). Biotechnological applications of marine photosynthetic bacteria, which utilize their ability to convert light energy into useful products, have recently been reported (Burgess, 1992; Burgess et al., 1993c). Recombinant DNA methods for marine Rhodospirillaceae (Matsunaga et al., 1986, 1990; Burgess et al., 1993a) and Chromatiaceae (Burgess et al., $1993 \mathrm{~b}$ ) have been established to enhance their biotechnological potential.

During this work an unusual isolate of marine Rhodobacter, strain NKPB 0021 was noticed. It was originally described in 1986 and tentatively identified as $R$. sphaeroides (Matsunaga et al., 1986). It also has a high rate of hydrogen photoproduction compared to other marine photosynthetic bacteria (Matsunaga et al., 1986). Later attempts to grow this strain aerobically, for conjugative gene transfer experiments, failed. Rhodobacter sp. strain NKPB 0021 was found to differ from $R$. sphaeroides in that it: cannot grow aerobically, has a high rate of hydrogen photoproduction and contains two endogenous cryptic plasmids of 5.4 and $7.0 \mathrm{~kb}$ respectively. We characterized this isolate in greater detail to establish its taxonomic position.

Six species of Rhodobacter have been described which are grouped into one genus of non-sulphur photosynthetic bacteria which contain vesicular intracytoplasmic membranes. R. sulphidophilus, R. adriaticus and R. euryhalinus are obligate halophiles. R. sulphidophilus has a remarkably high sulphide tolerance and can also grow aerobically in the dark. R. adriaticus is also tolerant to sulphide, but cannot grow under aerobic conditions.

We report here a new marine species of Rhodobacter which is obligately halophilic, unable to grow aerobically and sensitive to sulphide. The new species Rhodobacter marinus is proposed for this bacterium.

\section{METHODS}

Isolation and growth conditions. Rhodobacter marinus was isolated from samples of marine mud collected from coastal waters from the Izu peninsula, Japan. Enrichments were carried out using a marine RCVB medium (Beatty \& Gest, 1981; Matsunaga et al., 1990) of the following composition: $0.6 \mathrm{~g}$ $\mathrm{KH}_{2} \mathrm{PO}_{4}, \quad 0.9 \mathrm{~g} \quad \mathrm{~K}_{2} \mathrm{HPO}_{4}, \quad 0.2 \mathrm{~g} \quad \mathrm{MgSO}_{4} .7 \mathrm{H}_{2} \mathrm{O}, 12 \mathrm{mg}$ $\mathrm{FeSO}_{4} \cdot 7 \mathrm{H}_{2} \mathrm{O}, 20 \mathrm{mg} \mathrm{Na}{ }_{2} \mathrm{EDTA}, 1.25 \mathrm{~g} \mathrm{NH}_{4} \mathrm{Cl}, 15 \mathrm{~g} \mathrm{NaCl}$, $75 \mathrm{mg} \mathrm{CaCl}{ }_{2} \cdot 2 \mathrm{H}_{2} \mathrm{O}, 6 \mathrm{~g}$ DL-malate, $0.5 \mathrm{~g}$ yeast extract, $0.5 \mathrm{~g}$ peptone, $1 \mathrm{ml}$ trace metals [containing per $400 \mathrm{ml}$ distilled water: $\quad 1.12 \mathrm{~g} \quad \mathrm{H}_{3} \mathrm{BO}_{3}, \quad 0.84 \mathrm{~g} \quad \mathrm{MnSO}_{4} .4 \mathrm{H}_{2} \mathrm{O}, \quad 0.3 \mathrm{~g}$ $\mathrm{Na}_{2} \mathrm{MoO}_{4} \cdot 2 \mathrm{H}_{2} \mathrm{O}, \quad 96 \mathrm{mg} \quad \mathrm{ZnSO}_{4} .7 \mathrm{H}_{2} \mathrm{O}, \quad 16 \mathrm{mg}$ $\mathrm{Cu}\left(\mathrm{NO}_{3}\right)_{2} \cdot 3 \mathrm{H}_{2} \mathrm{O}$ ], $15 \mu \mathrm{g}$ biotin, dissolved in 1 litre of distilled water; $\mathrm{pH}$ adjusted to 7.6 with $\mathrm{NaOH}$ before autoclaving. 


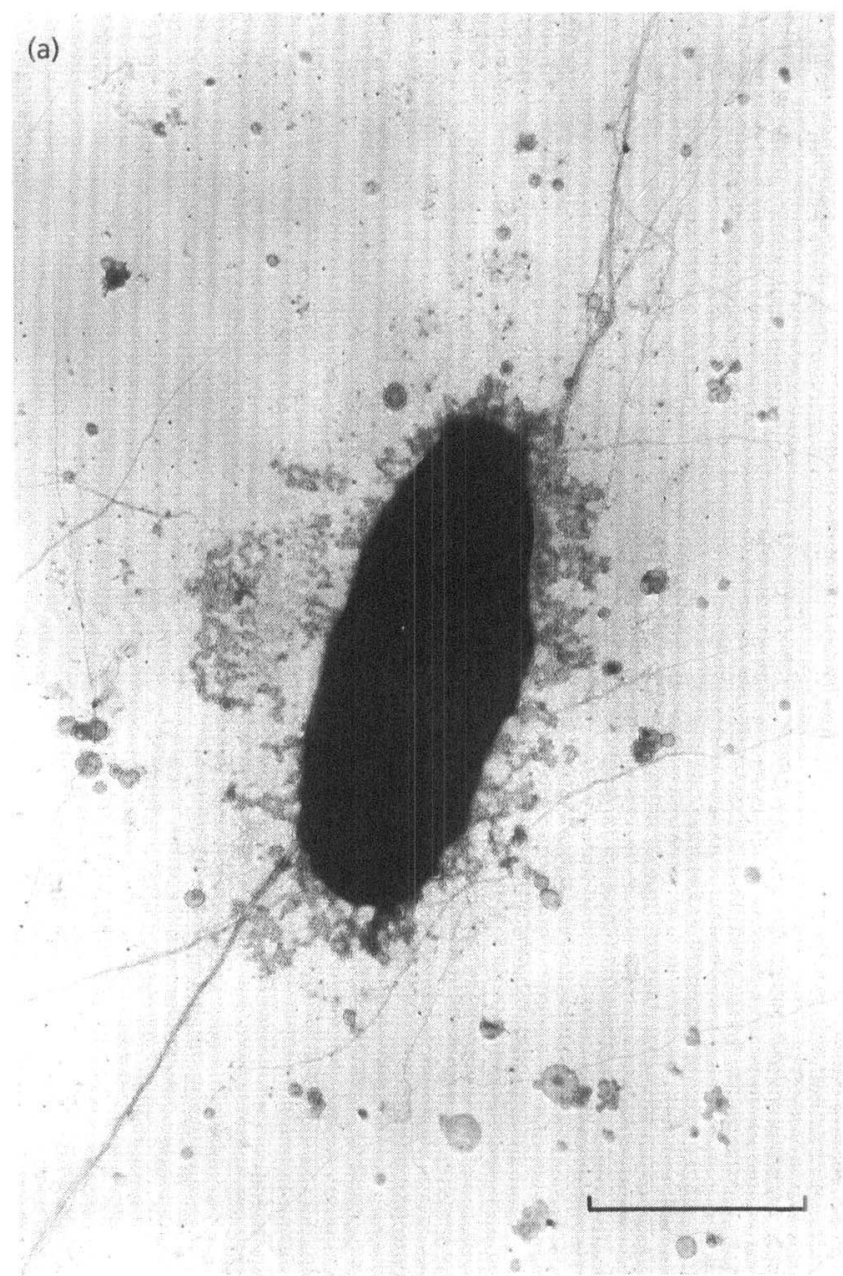

(b)

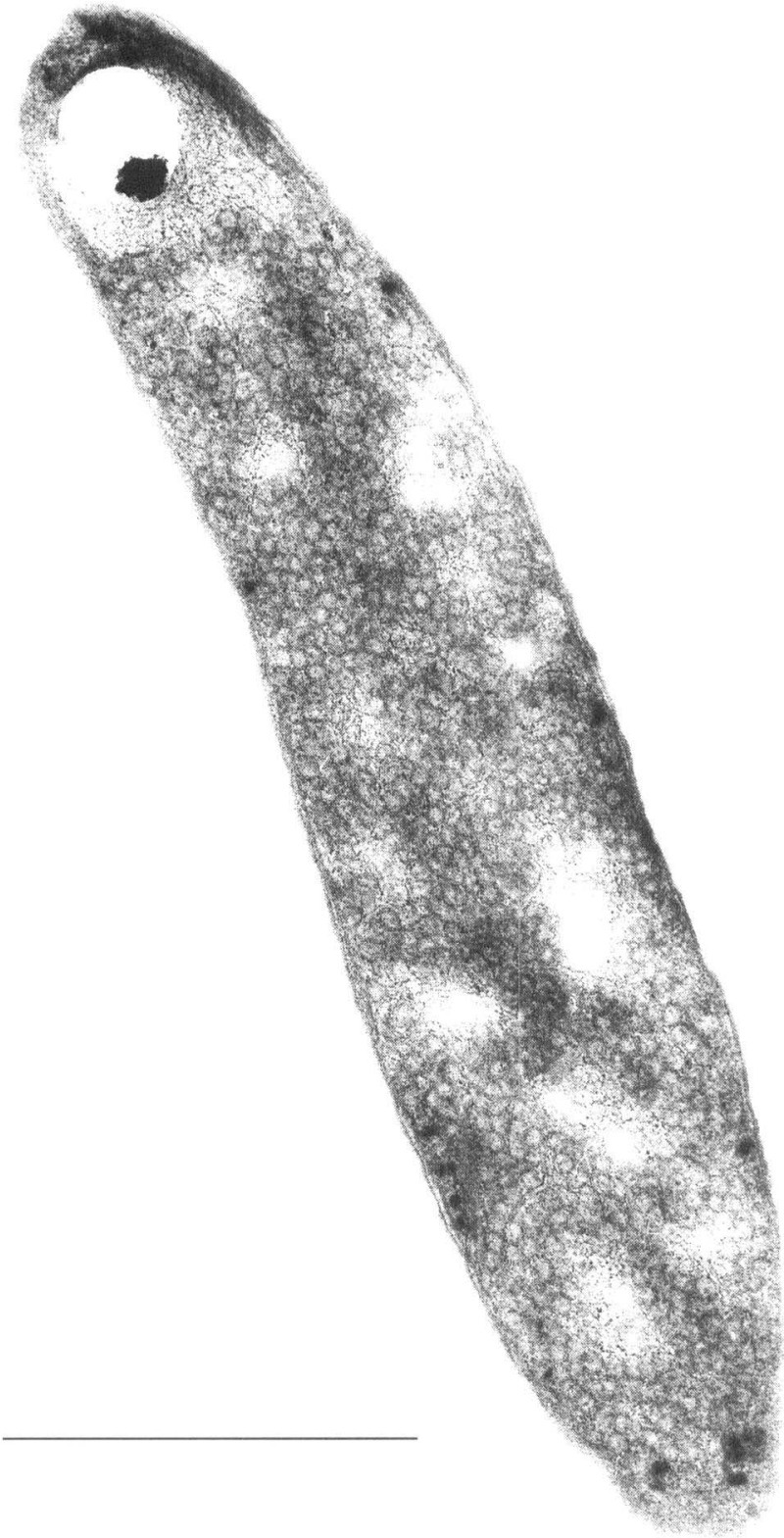

Fig. 1. (a) Negatively stained $R$. marinus cell showing flagella and fimbriae. (b) Thin section electron micrograph showing vesicular nature of the photosynthetic membranes and typical shape of a $R$. marinus cell. Bars, $1 \mu \mathrm{m}$.

R. marinus strain NKPB0021 is one of approximately 300 isolates of marine photosynthetic bacteria which were collected from coastal waters around Japan and form part of a culture collection of marine photosynthetic prokaryotes maintained within the Department of Biotechnology at Tokyo University of Agriculture and Technology. Marine broth 2216 (Difco) was used for purification of strain 0021 by serial dilution onto agar plates. This medium allowed separation from contaminants which were difficult to remove using other media. Cultures of $\mathrm{R}$. marinus were maintained at $30^{\circ} \mathrm{C}$ under continuous illumination with white fluorescent lamps at a light intensity of 500-600 lux.

Microscopy. Morphology and motility of liquid cultures were observed using an Olympus $\mathrm{BH} 2$ phase contrast microscope. Flagella were observed by negative staining and electron microscopy. Cells were suspended in $70 \mathrm{mM}$ phosphate buffer, $\mathrm{pH} 7 \cdot 0$, applied to coated copper grids, stained with uranyl acetate and observed with a transmission electron microscope (Hitachi $\mathrm{H}-700 \mathrm{H})$. For thin sections, cells were fixed with glutaraldehyde, post fixed with osmium tetroxide dehydrated in an ethanol series and embedded in epoxy resin. Sections were cut using an ultramicrotome, stained with uranyl acetate and lead citrate and observed under a transmission electron microscope.

Growth experiments. The optimum $\mathrm{NaCl}$ concentration was determined at $\mathrm{pH} 7.6$ and growth was followed over three passages in the same medium described above. To determine the effect of sulphide on growth, neutralized sodium sulphide was added in the range $0-3 \mathrm{mM}$. To study the effect of oxygen on growth, rubber stoppered $30 \mathrm{ml}$ test-tubes containing $10 \mathrm{ml}$ 
RCVB medium were evacuated using a vacuum pump and flushed repeatedly with argon until no oxygen was present in the gas phase, as determined by gas chromatography. Tubes were then injected with increasing amounts of oxygen and inoculated with $200 \mu \mathrm{l}$ of exponentially growing cells. In all cases, growth was followed by determining optical density (OD) at $660 \mathrm{~nm}$. For determination of vitamin requirement, cultures were grown for over three passages in marine RCVB medium which did not contain yeast extract, peptone or biotin. For growth experiments using seawater, RCVB medium was prepared as above with filtered seawater added instead of distilled water. To test the effect of nitrogen source on growth, ammonium chloride was replaced with equivalent concentrations of nitrate or molecular nitrogen.

Isolation of chromatophores and room temperature spectroscopy. R. sphaeroides ATCC 17023 was grown in RCVB medium without added $\mathrm{NaCl}$, and supplemented with $p$-aminobenzoic acid $\left(0 \cdot 3 \mathrm{mg} \mathrm{l}^{-1}\right)$ and nicotinic acid $\left(1 \mathrm{mg} \mathrm{l}^{-1}\right)$. Cells from 1 litre photosynthetic cultures were harvested by centrifugation and washed twice with $100 \mathrm{ml} \mathrm{TE}(10 \mathrm{mM}$ Tris/HCl, $1 \mathrm{mM}$ EDTA; $\mathrm{pH} 7 \cdot 5$ ). Cells were then resuspended in the same buffer to a final concentration of $0 \cdot 2-0.4 \mathrm{~g}$ wet wt $\mathrm{ml}^{-1}$ and disrupted by sonication. The broken cell extract was then layered onto a $15 \%-40 \%(\mathrm{w} / \mathrm{v})$ sucrose step gradient and after centrifugation for $4 \mathrm{~h}$ at $100000 \mathrm{~g}$, membranes were recovered from the interface (Niederman \& Gibson, 1978). Membranes were stored at $-20^{\circ} \mathrm{C}$ until required. Room temperature absorbance spectra were recorded using a Shimadzu UV-2200 recording spectrophotometer. Approximately $50 \mu \mathrm{l}$ of chromatophores was resuspended in $1 \mathrm{ml}$ of water so that the maximum absorbance at $850 \mathrm{~nm}$ was less than 1.

Determination of DNA base composition. Total DNA was extracted from 1 litre of culture by the method of Marmur and harvested by spooling onto a glass rod (Marmur, 1961). The guanine $(G)$ plus cytosine $(C)$ content of the DNA was determined by analysing $\mathrm{P} 1$ nuclease enzyme hydrolysates using HPLC (Katayama-Fujimura et al., 1984). Nucleotide standards were purchased as a $\mathrm{G}: \mathrm{C}$ determination kit from Yamasa Shoyu (Choshi, Japan).

\section{RESULTS}

\section{Morphology and ultrastructure}

Cells are Gram-negative ovoid rods, $0 \cdot 6-1 \cdot 2 \mu \mathrm{m}$ in diameter and 3-5 $\mu \mathrm{m}$ long when grown in RCVB medium. The thin section electron micrograph in Fig. 1 shows typical cell shape and size. Cells from late exponential to stationary growth phase are elongated and form viscous clumps due to the formation of slime. Cell aggregates in zig-zag or chain arrangements, which are characteristic of $R$. capsulatus were not observed. Cells from exponentially growing cultures are motile by means of polar flagella (Fig. 1a). Negative staining revealed the presence of numerous fimbriae, which were thinner and more numerous than the polar flagella. These covered the cell and are unusual in Rhodobacter species. When grown in medium containing seawater, cells rapidly formed large flocs. This phenomenon did not occur in defined medium. Exponentially growing cultures were dark brown to rust in colour, while colonies on agar plates appeared very dark brown. Cells appear to divide by binary fission. The photosynthetic membranes are present as vesicular intru- sions of the cytoplasmic membrane (Fig. 1b). The average size of the vesicles is small compared to freshwater species such as $R$. sphaeroides and seems to be more similar to chromatophores of some species of Chromatium (Remsen, 1978). Cells did not contain sulphur globules or gas vacuoles, and did not appear able to form spores.

\section{Physiology}

The most striking difference between R. marinus and R. sphaeroides is the inability of $R$. marinus to grow chemoheterotrophically under aerobic conditions. When a range of oxygen concentrations was used, growth did not occur or was marginal in the presence of oxygen (Fig. 2). A slight increase in cell number occurred when incubated in the dark at a $p \mathrm{O}_{2}$ of $0.025 \mathrm{~atm}$, but the final $\mathrm{OD}_{660}$ was less than $0 \cdot 4$. No growth occurred in the dark under strictly anaerobic conditions.

To determine whether $R$. marinus required $\mathrm{NaCl}$ or was halotolerant, growth rate was determined using RCVB medium containing a range of different salt concentrations. In the absence of $\mathrm{NaCl}$ no growth occurred, while at $4.5 \% \mathrm{NaCl}$ and above growth was greatly reduced compared to growth at $1.5 \%$, the optimum $\mathrm{NaCl}$ concentration (data not shown).

For determination of other growth characteristics, RCVB medium containing $1.5 \% \mathrm{NaCl}$ was used. The optimum $\mathrm{pH}$ was found to be $6-8$ with maximum growth occurring at $\mathrm{pH} 7 \cdot 6$. Growth was not affected by the removal of

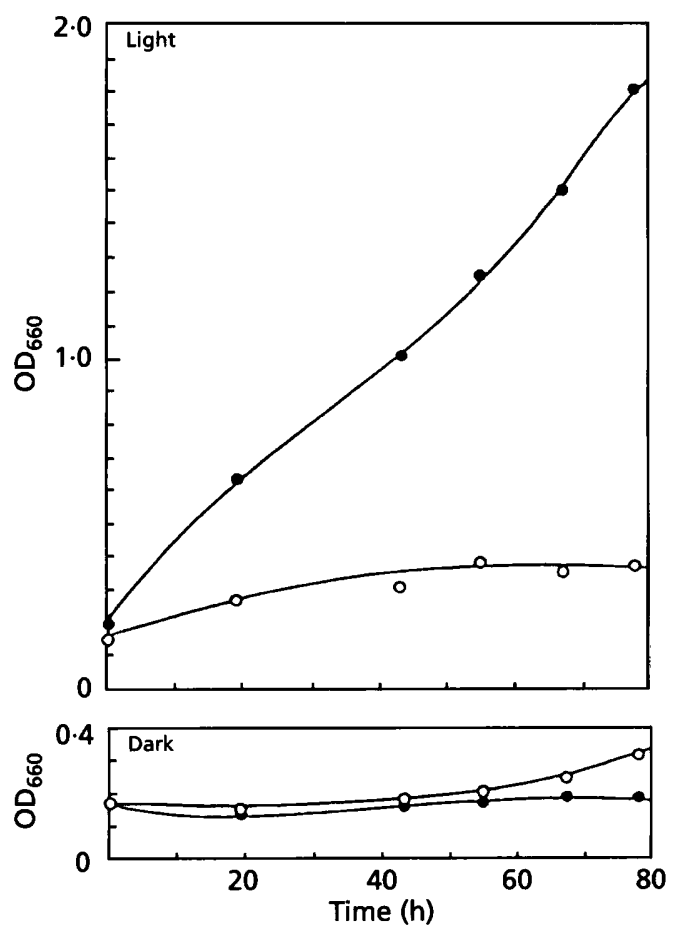

Fig. 2. Effect of oxygen on the growth of $R$. marinus strain NKPB 0021. Growth was measured in the light (photosynthetic) and dark conditions at oxygen partial pressures of $0 \mathrm{~atm}(\mathrm{O})$ and $0.025 \mathrm{~atm}(\mathrm{O})$. 
Table 1. Differentiating characteristics of species of the genus Rhodobacter

Data from Imhoff \& Trüper (1989) except for R. marinus, this work. Symbols: +, present or positive in most or all strains; - absent or negative in most or all strains; \pm present or positive in some strains but negative or absent in other strains; $t$, thiamin; $b, b i o t i n ; n$, niacin; $p$-aba, $p$-aminobenzoic acid; ND, not determined.

\begin{tabular}{|c|c|c|c|c|c|c|}
\hline & \multicolumn{3}{|c|}{ Freshwater } & \multicolumn{3}{|c|}{ Marine } \\
\hline & R. capsulatus & R. sphaeroides & R. veldkampii & R. sulfidophilus & R. adriaticus & R. marinus \\
\hline Cell diameter $(\mu \mathrm{m})$ & $0 \cdot 5-1 \cdot 2$ & $0 \cdot 7-4 \cdot 0$ & $0 \cdot 6-0 \cdot 8$ & $0 \cdot 6-0 \cdot 9$ & $0.5-0.8$ & $0 \cdot 6-1 \cdot 2$ \\
\hline Motility & + & + & - & + & - & + \\
\hline Slime formation & \pm & \pm & - & \pm & + & + \\
\hline $\mathrm{NaCl}$ requirement & - & - & - & + & + & + \\
\hline Growth factors required & $t$ & $\mathrm{~b}, \mathrm{t}, \mathrm{n}$ & $\mathrm{b}, \mathrm{t}, p$-aba & $\mathrm{b}, \mathrm{t}, \mathrm{n}, p$-aba & $\mathrm{b}, \mathrm{t}$ & - \\
\hline Aerobic growth & + & + & + & + & - & - \\
\hline \multicolumn{7}{|l|}{ Utilization of: } \\
\hline Tartrate & - & \pm & - & - & - & + \\
\hline Citrate & - & + & - & - & - & + \\
\hline Mannitol & - & + & - & - & - & + \\
\hline Glycerol & - & + & - & + & + & + \\
\hline Ethanol & - & + & - & \pm & + & - \\
\hline Gluconate & - & + & ND & + & ND & + \\
\hline Sulphide sensitivity & + & + & + & - & - & + \\
\hline$\% \mathrm{G}+\mathrm{C}$ Content & $68 \cdot 1-69 \cdot 6$ & $70 \cdot 8-73 \cdot 2$ & $64 \cdot 4-67 \cdot 5$ & $68 \cdot 9-73 \cdot 2$ & 66.7 & 66.7 \\
\hline
\end{tabular}
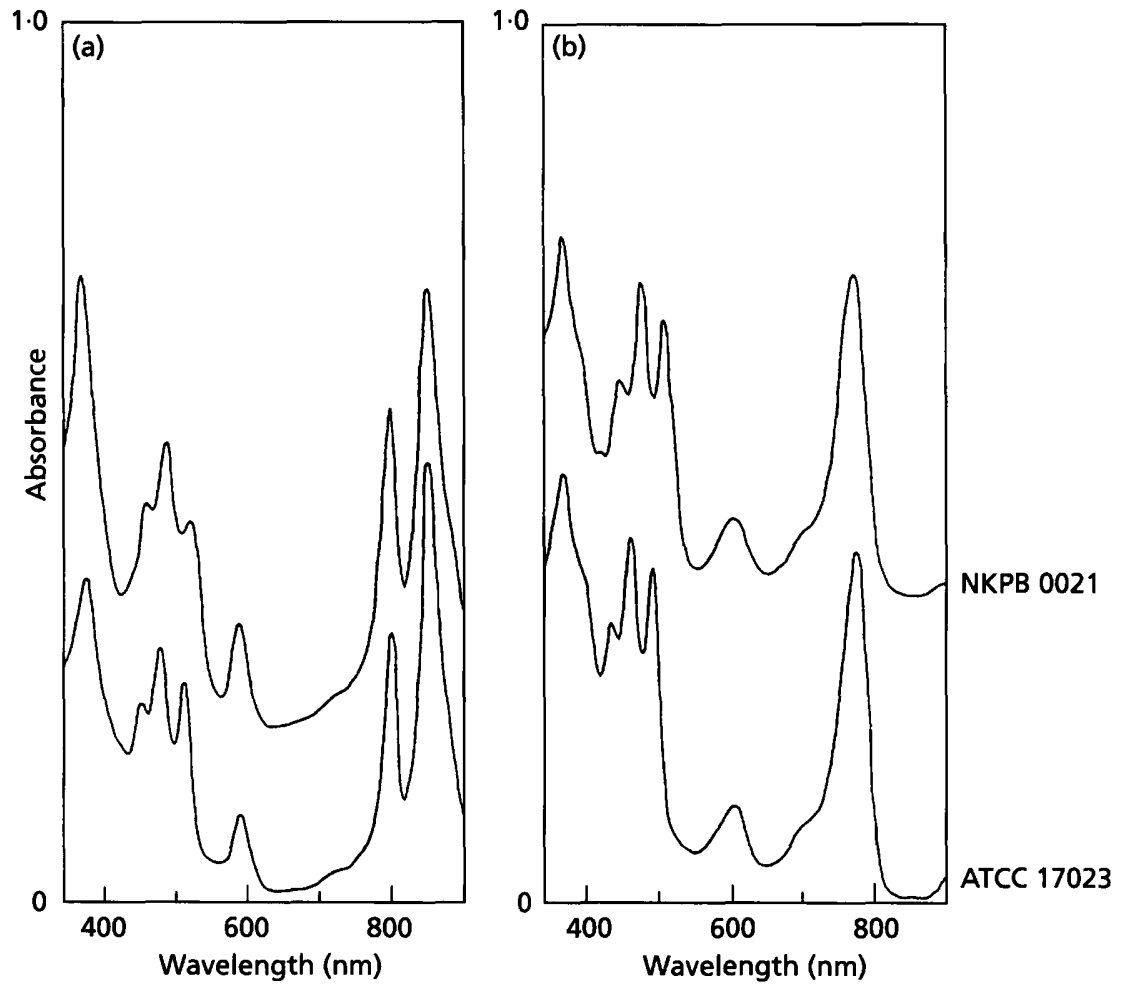

Fig. 3. Room temperature absorbance spectra of purified chromatophore membranes from R. marinus strain NKPB 0021 , and the freshwater species Rhodobacter sphaeroides 2.4.1 (ATCC 17023). (a) Spectra of membranes suspended in water; (b) acetone/methanol spectra of extracted pigments of the membrane samples. Chromatophores were prepared from photoheterotrophically grown cells. 
biotin from the medium over a number of generations. The presence of $0.1 \mathrm{mM}$ sodium sulphide slightly stimulated growth. Sulphide was oxidized to sulphate, and no deposition of elemental sulphur was observed. No growth occurred at $0.7 \mathrm{mM}$ sulphide. In the presence of malate as carbon source $R$. marinus grew well with sulphate as the sole sulphur source. Best growth was obtained with ammonia as the nitrogen source. The following carbon sources could be utilized by strain NKPB 0021 growing anaerobically in the light: acetate, propionate, butyrate, fumarate, lactate, malate, pyruvate, tartrate, citrate, gluconate, mannitol, sucrose, xylan, galactose, fructose, maltose, mannitol, xylose, glycerol, yeast extract, Casamino acids, valerate, succinate, glucose and mannose. However ethanol, caproate, caprylate, pelargonate, sorbitol, propanol, arginine and methanol were not utilized. Utilization of carbon sources which may be used to distinguish species of the genus $R$ hodobacter are shown in Table 1. R. marinus is also sensitive to penicillin with a minimum inhibitory concentration of $1 \mathrm{U} \mathrm{ml}^{-1}$.

\section{Photosynthetic pigments}

The absorption spectrum of intact cells of $R$. marinus is almost identical to the absorption spectrum of $R$. sphaeroides (data not shown). To record a spectrum unaffected by light scattering, photosynthetic membranes were isolated as described in Methods. Absorption spectra of the two species were almost indistinguishable (Fig. 3). The absorbance peaks at 372-375, 446-450, 474-481, 500, $590,800,850$ and the shoulder at $870-880$ are indicative of bacteriochlorophyll $a$, and carotenoids of the spheroidene series.

\section{DNA analysis}

The $G+C$ content of $R$. marinus strain NKPB 0021 was $66.7 \mathrm{~mol} \%$ as determined by HPLC.

\section{DISCUSSION}

A marine photosynthetic bacterium, strain NKPB 0021, has been identified as a new species of Rhodobacter. This bacterium can evolve large quantities of hydrogen when grown photosynthetically (Matsunaga et al., 1986), and has recently been used for gene cloning and expression studies in this laboratory (Burgess et al., 1993a, c; Matsunaga et al., 1990). Cells are most similar to R. sphaeroides with regard to morphology and absorption spectra, but differ in a number of properties from all previously described species of Rhodobacter.

The requirement for $\mathrm{NaCl}$ and the observation that similar strains could not be isolated from freshwater habitats imply that $R$. marinus is an indigenous marine species. Only three species of purple non sulphur bacteria were previously regarded as indigenous marine bacteria; R. sulfidophilus (Hansen \& Veldkamp, 1973), R. adriaticus (Neutzling et al., 1984) and Rhodopseudomonas marina (Imhoff, 1983). R. sulfidophilus and R. adriaticus are relatively resistant to sulphide $(3-5 \mathrm{mM})$, which is consistent with their isolation from sulphide-containing environments. Conversely, Rps. marina is relatively sensitive to sulphide $(0 \cdot 4-0.8 \mathrm{mM})$. Most of the purple non sulphur bacteria known at present (about 25 species) were isolated from freshwater sources and, with a few exceptions, are very sensitive to even low concentrations of sulphide.

R. marinus is also sensitive to oxygen, being able to grow only slowly in the dark at an optimal $p \mathrm{O}_{2}$ of $2.5 \times 10^{-2} \mathrm{~atm}$. This is similar to R. adriaticus which also grows very slowly under microaerophilic conditions (Neutzling et al., 1984) although the extent of its oxygen sensitivity was not measured. R. marinus may be distinguished from $R$. adriaticus as it can assimilate sulphate as the sole sulphur source whereas $R$. adriaticus requires reduced sulphur compounds. Carbon source requirements also differ. The salinity optimum of $1.5 \% \mathrm{NaCl}$ for R. marinus NKPB 0021 is lower than that both for marine $R$. sulfidopbilus and for marine R. adriaticus, which have a higher optimum at $2.5 \%$. With R. adriaticus, growth is also possible in $10 \% \mathrm{NaCl}$.

R. marinus is also unique as it is the only member of the genus Rhodobacter which does not require thiamin for growth (Imhoff \& Trüper, 1989). Species of Rhodospirillum and Chromatium which do not require vitamins or additional growth factors have also been previously reported (Drews, 1981; Gest et al., 1985). Utilization of ethanol, caproate, caprylate, pelargonate and sorbitol by $R$. sphaeroides, but not by R. marinus, may be used to distinguish these two species. Table 1 provides a useful key for distinguishing species of the genus Rhodobacter. Details of an additional species, $R$. eurybalinus, are not shown; however R. marinus may be distinguished from R. eurybalinus since R. eurybalinus requires four vitamins for growth, can grow aerobically and is not capable of assimilatory sulphate reduction. Moreover, cultures of R. eurybalinus can use sulphide as electron donor, with elemental sulphur being deposited outside the cells, and can grow in a wide range of salinities (Kompantseva, 1985).

R. marinus strain NKPB 0021 appears to be a marine Rhodobacter which is not suited to growth in sulphidecontaining habitats, as are the other marine species of this genus; R. sulfidophilus, R. adriaticus and R. eurybalinus. Since R. marinus is also sensitive to oxygen, its ecological habitat would appear to be restricted to a zone in marine sediments below the surface aerobic layers but above the deeper layers of sediment where sulphate reducing bacteria cause accumulation of sulphide (Jørgensen, 1983). It is interesting to note that in this zone one would also expect to find a small amount of sulphide which has diffused upwards through the pore-water (Jørgensen, 1983) so it is expected that small quantities of sulphide $(0.14 \mathrm{mM})$ stimulate growth of $\mathrm{R}$. marinus which would have presumably adapted to such conditions.

\section{Species description}

Rhodobacter marinus sp. nov. ma.ri'nus. L. fem. adj. marinus marine. Cells are straight rods, $0 \cdot 6-1 \cdot 2 \mu \mathrm{m}$ in diameter and motile by means of polar flagella. They are Gram- 
negative, multiply by binary fission, photosynthetic membranes are of the vesicular type, pigments are bacteriochlorophyll $a$ and carotenoids of the spheroidene series.

Growth is possible anaerobically by photosynthesis, very slow growth may occur in the dark in the presence of low levels of oxygen. Sensitive to oxygen, addition of Na-ascorbate stimulates growth. Photoorganotrophy with a wide range of carbon sources as the electron donors is the preferred mode of growth. Electron donors not used include ethanol, caproate, caprylate, pelargonate and sorbitol. Sensitive to sulphide, sulphate assimilated as sole sulphur source. Optimum growth at $25-35^{\circ} \mathrm{C}, \mathrm{pH} 7 \cdot 6$, $1.5 \% \mathrm{NaCl}$. No growth factors are required. DNA base composition of the type strain is $66.7 \mathrm{~mol} \% \mathrm{G}+\mathrm{C}$. Source: marine mud from coastal water of Japan. Type strain NKPB 0021 is available from the culture collection of photosynthetic bacteria at Tokyo University of Agriculture and Technology (strain NKPB 0021), or from the German Collection of Microorganisms type strain DSM 8973.

\section{ACKNOWLEDGEMENTS}

We thank Professor Megumi Okazaki of Tokyo Gakugei University for the electron micrographs and Dr Yoko Katayama of the Faculty of Agriculture, Tokyo University of Agriculture and Technology for assistance with the G:C content determination by HPLC.

\section{REFERENCES}

Beatty, J. T. \& Gest, H. (1981). Generation of succinyl coenzyme A in photosynthetic bacteria. Arch Microbiol 129, 335-340.

Burgess, J. G. (1992). Biotechnological applications of photosynthetic bacteria. Trans Mat Res Soc Japan 10, 16-24.

Burgess, J. G., Sudo, H., Sode, K. \& Matsunaga, T. (1993a). Efficient gene transfer of high copy number mobilizable plasmids containing a marine Rbodobacter origin of replication. Curr Microbiol 26, 105-108.

Burgess, J. G., Sudo, H., Sode, K. \& Matsunaga, T. (1993b). Gene transfer in Chromatium purpuratum, a marine sulphur photosynthetic bacterium producing antibiotics. J Mar Biotechnol 1, 101-104.

Burgess, J. G., Tsubaki, K. \& Matsunaga, T. (1993c). Expression of yellow tail (Seriola quinqueradiata) fish growth hormone cDNA in the marine photosynthetic bacterium Rhodobacter sp. NKPB0021. Biotechnol Lett 15, 111-114.

Drews, G. (1981). Rhodospirillum salexigens, spec. nov., an obligatory halophilic phototrophic bacterium. Arch Microbiol 130, 325-327.

Gest, H., Favinger, J. L. \& Madigan, M. T. (1985). Exploitation of
$\mathrm{N}_{2}$-fixation capacity for enrichment of anoxygenic photosynthetic bacteria in ecological studies. FEMS Microbiol Ecol 31, 317-322.

Hansen, T. A. \& Veldkamp, H. (1973). Rhodopseudomonas sulfidophila, nov. spec., a new species of the purple nonsulfur bacteria. Arch Microbiol 92, 45-48.

Imhoff, J. F. (1983). Rhodopseudomonas marina sp. nov., a new marine phototrophic purple bacterium. Syst Appl Bacteriol 4, 512-521.

Imhoff, J. F. \& Truper, H. G. (1989). Purple nonsulfur bacteria. In Bergey's Manual of Systematic Bacteriology, vol. 3, pp. 1658-1682. Edited by J. T. Staley, M. P. Bryant, N. Pfennig \& J. G. Holt. Baltimore: Williams \& Wilkins.

Jørgensen, B. B. (1983). Processes at the sediment water-interface. In The Major Biogeochemical Cycles and their Interactions, pp. 477-509. Edited by B. Bolin \& R. B. Cook. New York: John Wiley and Sons.

Katayama-Fujimura, Y., Komatsu, Y., Kuraishi, H. \& Kaneko, T. (1984). Estimation of DNA base composition by high performance liquid chromatography of its nuclease P1 hydrolysate. Agric Biol Chem 48, 3169-3172.

Kompantseva, E. I. (1985). Rhodobacter eurybalinus sp. nov., a new halophilic purple bacterial species. Mikrobiologiya 54, 974-982.

Marmur, J. (1961). A procedure for the isolation of deoxyribonucleic acid from microorganisms. $J$ Mol Biol 3, 208-218.

Matsunaga, T., Matsunaga, N., Tsubaki, K. \& Tanaka, T. (1986). Development of a gene cloning system for the hydrogen producing marine photosynthetic bacterium Rhodopseudomonas sp. J Bacteriol 168, 460-463.

Matsunaga, T., Tsubaki, K., Miyashita, H. \& Burgess, J. G. (1990). Chloramphenicol acetyltransferase expression in marine Rhodobacter sp NKPB0021 by use of shuttle vectors containing the minimal replicon of an endogenous plasmid. Plasmid 24, 90-99.

Neutzling, O., Imhoff, J. F. \& Truper, H. G. (1984). Rhodopseudomonas adriatica sp. nov., a new species of the Rhodospirillaceae dependent on reduced sulfur compounds. Arch Microbiol 137, 256-261.

Niederman, R. A. \& Gibson, K. D. (1978). Isolation and physicochemical properties of membranes from purple photosynthetic bacteria. In The Photosynthetic Bacteria, pp. 79-118. Edited by R. K. Clayton \& W. R. Sistrom. New York \& London: Plenum Press.

Remsen, C. C. (1978). Comparative subcellular architecture of photosynthetic bacteria. In The Photosynthetic Bacteria, pp. 31-60. Edited by R. K. Clayton \& W. R. Sistrom. New York \& London: Plenum Press.

Scolnik, P. \& Marrs, B. L. (1987). Genetic research with photosynthetic bacteria. Annu Rev Microbiol 41, 703-726.

Willison, J. C. (1993). Biochemical genetics revisited: the use of mutants to study carbon and nitrogen metabolism in the photosynthetic bacteria. FEMS Microbiol Rev 104, 1-38.

Received 5 April 1993; revised 7 December 1993; accepted 20 December 1993. 